Check for updates

Cite this: Phys. Chem. Chem. Phys., 2020, 22, 18976

Received 4th March 2020,

Accepted 2nd July 2020

DOI: $10.1039 / \mathrm{d} 0 \mathrm{cp} 01227 \mathrm{k}$

rsc.li/pccp

\section{Operando potassium K-edge X-ray absorption spectroscopy: investigating potassium catalysts during soot oxidation $\dagger$}

\author{
Catherine J. Davies, ${ }^{\mathrm{a}}$ Alexander Mayer, ${ }^{\mathrm{b}}$ Jess Gabb, ${ }^{\mathrm{a}}$ Jake M. Walls, (D) ${ }^{\mathrm{b}}$ \\ Volkan Degirmenci, (D) ${ }^{c}$ Paul B. J. Thompson, ${ }^{\text {de }}$ Giannantonio Cibin, ${ }^{f}$ Stan Golunski ${ }^{a}$ \\ and Simon A. Kondrat (D)*b
}

\begin{abstract}
The chemical and structural nature of potassium compounds involved in catalytic soot oxidation have been studied by a combination of temperature programmed oxidation and operando potassium $\mathrm{K}$-edge $X$-ray absorption spectroscopy experiments. These experiments are the first known operando studies using tender $\mathrm{X}$-rays $(\sim 3.6 \mathrm{keV})$ under high temperature oxidation reaction conditions. $\mathrm{X}$-ray absorption near edge structure analysis of $\mathrm{K}_{2} \mathrm{CO}_{3} / \mathrm{Al}_{2} \mathrm{O}_{3}$ catalysts during heating shows that, at temperatures between 100 and $200{ }^{\circ} \mathrm{C}$, potassium species undergo a structural change from an initial hydrated $\mathrm{K}_{2} \mathrm{CO}_{3} \cdot x \mathrm{H}_{2} \mathrm{O}$ and $\mathrm{KHCO}_{3}$ mixture to well-defined $\mathrm{K}_{2} \mathrm{CO}_{3}$. As the catalyst is heated from $200{ }^{\circ} \mathrm{C}$ to $600{ }^{\circ} \mathrm{C}$, a feature associated with multiple scattering shifts to lower energy, indicating increased $\mathrm{K}_{2} \mathrm{CO}_{3}$ dispersion, due to its mobility at high reaction temperature. This shift was noted to be greater in samples containing soot than in control experiments without soot and can be attributed to enhanced mobility of the $\mathrm{K}_{2} \mathrm{CO}_{3}$, due to the interaction between soot and potassium species. No potassium species except $\mathrm{K}_{2} \mathrm{CO}_{3}$ could be defined during reactions, which excludes a potential reaction mechanism in which carbonate ions are the active soot-oxidising species. Simulations of $\mathrm{K}$-edge absorption near edge structures were performed to rationalise the observed changes seen. Findings showed that cluster size, unit cell distortions and variation in the distribution of potassium crystallographic sites influenced the simulated spectra of $\mathrm{K}_{2} \mathrm{CO}_{3}$. While further simulation studies are required for a more complete understanding, the current results support the hypothesis that changes in the local structure on dispersion can influence the observed spectra. Ex situ characterisation was carried out on the fresh and used catalyst, by $\mathrm{X}$-ray diffraction and X-ray photoelectron spectroscopy, which indicated changes to the carbonate species, in line with the $\mathrm{X}$-ray absorption spectroscopy experiments.
\end{abstract}

\section{Introduction}

Alkali metal compounds, such as potassium, have a longestablished role in heterogeneous catalysis as promotors ${ }^{1-6}$ or act as catalytic poisons. ${ }^{7-10}$ These properties are attributed to

\footnotetext{
${ }^{a}$ Cardiff Catalysis Institute, School of Chemistry, Cardiff University, Main Building, Park Place, Cardiff, CF10 3AT, UK

${ }^{b}$ Department of Chemistry, Loughborough University, Loughborough, Leicestershire, LE113TU, UK. E-mail: s.kondrat@lboro.ac.uk

${ }^{c}$ The School of Engineering, University of Warwick, Coventry, CV4 7AL, UK

${ }^{d}$ XMaS, UK CRG, ESRF, 71 Avenue des Martyrs, 38043 Grenoble, France

${ }^{e}$ Department of Physics, University of Liverpool, Oliver Lodge Laboratory, Liverpool L69 7ZE, UK

${ }^{f}$ Diamond Light Source Ltd, Harwell Science and Innovation Campus, Didcot, OX11 ODE, UK

† Electronic supplementary information (ESI) available. See DOI: 10.1039/ d0cp01227k
}

different alkali-adsorbate interactions; such as (1) the interaction of an alkali-surface electrostatic field and the adsorbate, ${ }^{11}$ (2) long range interactions mediated by surface electrons ${ }^{12}$ or (3) the direct orbital overlap between the alkali cation and the adsorbate to provide a lower transition state for a given reaction. ${ }^{13-15}$ In some reactions, such as the gasification and oxidation of elemental carbon, ${ }^{16-18}$ alkali compounds alone show reactivity. In addition to the complexity of molecular level mechanisms, other considerations around the role of alkali compounds should be considered, such as their local structure, stability and surface mobility.

Many mechanistic studies of alkali species in catalysis have used ultra-high vacuum (UHV) experiments, with single crystal catalyst models. ${ }^{10,12,14,19}$ These informative studies have helped address fundamental surface science discussed above. Yet due to the much-discussed pressure and materials gaps, alternative experiments using working catalysts require alternative approaches. 
X-ray photoelectron spectroscopy (XPS) and X-ray absorption spectroscopy (XAS) of prior and post reaction powdered catalysts, more closely related to applied catalytic materials have been reported. ${ }^{20-23}$

Operando spectroscopy, which is the spectroscopic study of a catalyst while simultaneously measuring its catalytic performance, could provide an opportunity to observe alkali compound speciation and dispersion during a catalytic reaction. However, this is not without significant technical challenge. Alkali compounds are usually present as a low weight fraction of poorly crystalline surface species on a matrix of crystalline metals and metal oxides, making specific observations of their properties challenging when using many characterisation techniques. XAS at the K-edge energies of alkali promotors allows for direct measurement of these compounds' local structure.

With the aim of understanding alkali species during a particularly challenging catalytic reaction, under realistic conditions, we carried out potassium K-edge XAS of a $10 \mathrm{wt} \% \mathrm{~K} / \alpha$ $\mathrm{Al}_{2} \mathrm{O}_{3}$ catalyst performing soot oxidation. To our knowledge, this is the first attempt of operando potassium K-edge XAS study reported. There exists only two other in situ studies reported to date: (1) the potassium promoted cobalt FischerTropsch catalysts reported by Huffman et al., ${ }^{24}$ and (2) the evolution of calcium or potassium species during the pyrolysis of lignite chars by Huggins et $a .^{25}$ The tender energy of the potassium K-edge makes operando experiments, where reactant and gases are contained within a reaction vessel, viable. Also, potassium species are active for soot oxidation in the absence of other catalytic species, such as Pt, enabling a simple supported potassium catalyst to be used. Further, the oxidation of soot is a well-researched topic with significant application in the automotive industry. In particular, the passive regeneration of diesel particulate filters, by combustion of the soot, requires the porous ceramic filter material to be coated in a catalyst to lower combustion temperatures to within the range of engine exhaust-gas temperatures. ${ }^{26}$ Several different catalyst formulations including noble metals and various metal oxides have been reported, with the addition of alkali promotors substantially lowering the onset temperature for soot combustion. ${ }^{26-31}$

These alkali compounds are hypothesised to form high surface area oxides and superoxide species, which are key intermediates in the oxidation reaction. ${ }^{32-34}$ The electro-positivity of alkali metal and alkaline earth compounds correlates with lowering of reaction temperatures, suggesting that electron donation from the alkali weakens $\mathrm{C}-\mathrm{C}$ bonds. ${ }^{35}$ In an alternative mechanism (which owes much to the routes proposed for carbon gasification), alkali-metals are assumed to form carbonates as the thermodynamically stable species under exhaust gas conditions. ${ }^{34,36}$ If elemental carbon comes into contact with an alkali metal carbonate, it can reduce the carbonate to the metal oxide and/or superoxide (e.g. as shown for potassium in eqn (1)), which in turn can transform back to the carbonate by reaction with $\mathrm{CO}_{2}$ from the exhaust gas (eqn (2)). In a fuel-lean exhaust gas (as produced by a diesel engine), the CO formed in eqn (1) can immediately be catalytically oxidised to $\mathrm{CO}_{2}$.

$$
\text { Soot oxidation: } \mathrm{K}_{2} \mathrm{CO}_{3}+\mathrm{C} \rightarrow \mathrm{K}_{2} \mathrm{O}+2 \mathrm{CO}
$$

Regeneration of active species: $\mathrm{K}_{2} \mathrm{O}+\mathrm{CO}_{2} \rightarrow \mathrm{K}_{2} \mathrm{CO}_{3}$

A further characteristic found to be important, when alkali metal compounds are used as catalyst promoters, is their mobility on the catalyst surface, which increases the soot-catalyst contact. $^{33,35}$ While potassium compounds have been reported to be among the most reactive under loose contact conditions, the exact nature of the catalytic species and its dispersion under reaction conditions is not known. Therefore, the reported operando potassium K-edge XAS study is aimed to shed light on the nature and dispersion of potassium species in soot oxidation and, more generally, to present a proof of concept for operando experiments to provide insight into alkali compounds in catalysis. Our findings from these operando experiments have been supported by more conventional application of ex situ XRD and XPS before and after reaction with soot.

\section{Experimental}

\section{Catalyst preparation}

$\mathrm{K}_{2} \mathrm{CO}_{3}(0.3538 \mathrm{~g}$, Aldrich, 99.995\%) was dissolved in deionised water $(5 \mathrm{ml})$ and heated with stirring in an oil bath at $80{ }^{\circ} \mathrm{C}$. $\alpha-\mathrm{Al}_{2} \mathrm{O}_{3}$ (1.80 g, Alfa Aesar, 99.9\%) was added, the temperature increased to $110{ }^{\circ} \mathrm{C}$ and stirred for $30 \mathrm{~min}$ until a thick paste was obtained. The paste was dried overnight $(16 \mathrm{~h})$ at $110{ }^{\circ} \mathrm{C}$ prior to calcination in static air for $5 \mathrm{~h}$ at $500{ }^{\circ} \mathrm{C}$, heated at a ramp rate of $10{ }^{\circ} \mathrm{C} / \mathrm{min}$. The catalyst is referred to as $\mathrm{K} / \alpha-\mathrm{Al}_{2} \mathrm{O}_{3}$ throughout.

\section{Catalyst testing}

Soot oxidation light off temperature was tested using thermalgravimetric analysis (TGA) on a Setaram TGA-DTA/DSC instrument. Catalyst was mixed in 'loose contact' (to mimic the degree of catalyst-soot contact in a catalytic soot filter as it begins to trap soot particulate from an exhaust gas ${ }^{26}$ ) with carbon black (which has been determined to be a representative model of the elemental carbon component of diesel $\operatorname{soot}^{26}$ ), by stirring together in a vial for approx. $1 \mathrm{~min}$, in a 10:1 catalyst to soot ratio by mass. The mixture was heated to $900{ }^{\circ} \mathrm{C}$ at a rate of $5{ }^{\circ} \mathrm{C} \min ^{-1}$ in an air atmosphere.

\section{Characterisation}

XRD was carried out on a Panalytical X'Pert Pro diffractometer with Ni-filtered $\mathrm{Cu} \mathrm{K}_{\alpha}$ radiation, at $40 \mathrm{~mA}$ and $40 \mathrm{kV}$, with $20^{\circ}<2 \theta<80^{\circ}$. The phases present were confirmed by matching patterns to the ICSD. XPS was carried out using a Kratos AXIS ULTRA-DLD spectrometer, using monochromatic $\mathrm{Al}-\mathrm{K}_{\alpha}$ radiation (photon energy $=1486.6 \mathrm{eV}$ ), under ultra-high vacuum. The data obtained was achieved at a pass energy of $40 \mathrm{eV}$, and the analysis of the data from the scans was carried out in CasaXPS ${ }^{\mathrm{TM}}$ software, with all peaks calibrated to the $\mathrm{C}(1 \mathrm{~s})$ which has a binding energy of $284.7 \mathrm{eV}$.

X-ray Absorption Near Edge Structure (XANES) experiments were performed on beamline BM28 (XMaS) at the European 
Synchrotron Radiation Facility (ESRF), Grenoble, France. Data were collected at the Potassium K-Edge in fluorescence mode both in operando and ex situ measurements using silicon drift diode detectors. Ex situ samples were adhered to carbon tape, while operando measurements were carried out using a custommade stainless-steel controlled atmosphere cell (shown in Scheme $\mathrm{S} 1, \mathrm{ESI} \dagger)$. The cell was heated with two fire rods controlled by a temperature controller. A thermocouple was placed close to the catalyst sample. Typically, a predetermined amount of finely ground sample was pressed in a stainless-steel holder and placed in the cell. Carbon foils were held between two high-purity carbon spacers. Gases were delivered by thermal mass flow controllers (Bronkhorst) and the outlet line was connected to a Hiden QGA mass spectrometer. The operando experiments were designed to reproduce as closely as possible the protocol (above) used for catalyst testing, which in turn was intended to mimic the catalystsoot interactions in a catalytic filter. Mixtures of $10: 1$ catalyst to soot (by mass) were loosely mixed and pressed (with minimum compression) into a coherent pellet and placed into the cell. Given that the proposed experiment was to study soot combustion, there was a clear concern that the graphite windows would also combust. However, physical separation of the catalyst/soot pellet, coupled with the intimate contact of the catalyst and reactant, provided a sufficient operating temperature window (up to $600{ }^{\circ} \mathrm{C}$ )

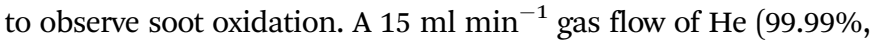
Air Liquide) or $20 \% \mathrm{O}_{2}$ balanced with $\mathrm{He}$ (Air Liquide) was used to purge the reaction cell and the outlet was continuously monitored by mass spectrometer. The sample temperature was then stabilised at $30{ }^{\circ} \mathrm{C}$ for $20 \mathrm{~min}$ before being heated at $2{ }^{\circ} \mathrm{C} \mathrm{min}^{-1}$ to $600{ }^{\circ} \mathrm{C}$. XANES measurements were obtained sequentially throughout the heating ramp, with the temperature being recorded. Confidence of measurement errors were estimated to be $\pm 0.1 \mathrm{eV}$ of reported positions.

\section{XANES simulation}

XANES simulations were performed with FEFF9.05 $\operatorname{code}^{37,38}$ starting from cif structures (ICSD Collection Code 66943 and ICSD Collection Code 2074). Simulations were run on the K K edge using self-consistent field (SCF) molecular electron densities calculated over a cluster including 31 atoms. The Hedin-Lundqvist self-energy has been used for calculation of the exchange correlation potential with a correction to $\mathrm{K} 1$ and $\mathrm{K} 2$ of -2.269 and $-1.826 \mathrm{eV}$ on the Fermi energy. The full multiple scattering contributions have been calculated using a sphere including 6 to 223 atoms. The energy resolution was set to $0.3 \mathrm{eV}$ near the edge and $0.05 \AA^{-1}$ in the near EXAFS region up to $5 \AA^{-1}$. S02 amplitude has been fixed to 1 . When comparing simulations to experimental data the energy was shifted by $4 \mathrm{eV}$ in alignment with feature $\mathrm{A}$ of the experimental data.

\section{Results and discussion}

\section{Catalyst testing and $e x$ situ characterisation}

Prior to testing within the operando XAFS cell, the catalytic performance of $\mathrm{K} / \alpha-\mathrm{Al}_{2} \mathrm{O}_{3}$ was studied by performing soot

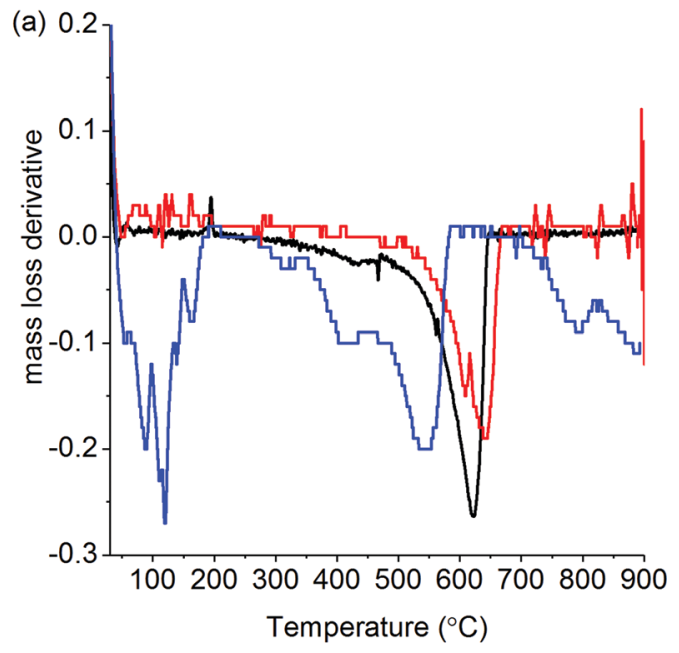

(b)

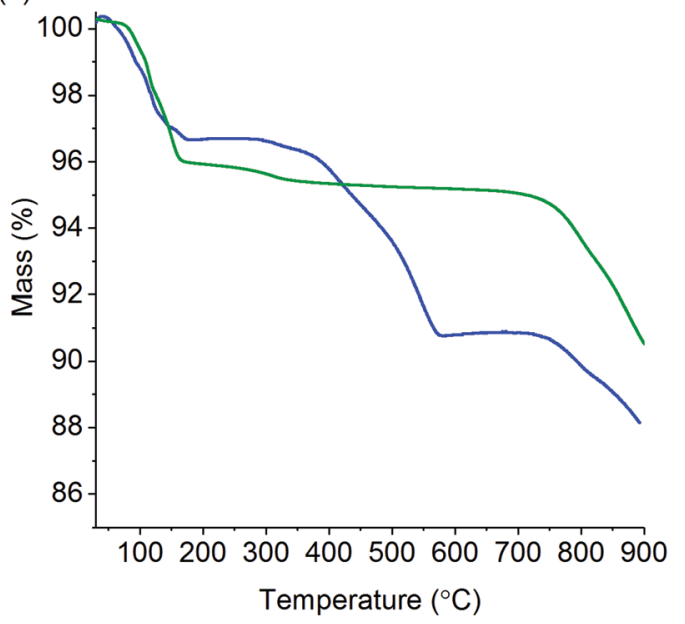

Fig. 1 Thermogravimetric analysis of soot oxidation. Experiments performed under an air atmosphere with a ramp rate of $5{ }^{\circ} \mathrm{C} \mathrm{min}^{-1}$. (a) Derivative of mass losses of soot (black line), $\alpha-\mathrm{Al}_{2} \mathrm{O}_{3}+$ soot (red line) and $\mathrm{K} / \alpha-\mathrm{Al}_{2} \mathrm{O}_{3}+$ soot (blue line). (b) Thermogravimetric profile of $\mathrm{K} / \alpha-\mathrm{Al}_{2} \mathrm{O}_{3}+$ soot decomposition (blue line) and $\mathrm{K} / \alpha-\mathrm{Al}_{2} \mathrm{O}_{3}$ (green line).

oxidation via TGA and characterised using ex situ XRD and XPS. Fig. 1 shows the derivative of the mass loss (dTG) for soot alone, soot mixed with $\alpha-\mathrm{Al}_{2} \mathrm{O}_{3}$ and soot mixed with $\mathrm{K} / \alpha-\mathrm{Al}_{2} \mathrm{O}_{3}$. In the absence of any additional material, the combustion of soot began at $500{ }^{\circ} \mathrm{C}$ and, following a slow induction, gave rise to a sharp non-symmetrical peak with a maximum at $625{ }^{\circ} \mathrm{C}$. The non-symmetrical peak shape closely resembles that observed during combustion of real diesel soot, ${ }^{26}$ though the position of the peak in Fig. 1 is about $30^{\circ} \mathrm{C}$ lower. When mixed with $\alpha-\mathrm{Al}_{2} \mathrm{O}_{3}$, the position of the soot combustion peak was shifted to a slightly higher temperature, so that it now reached its maximum at $640{ }^{\circ} \mathrm{C}$. This is consistent with the $\alpha-\mathrm{Al}_{2} \mathrm{O}_{3}$ having a diluting effect, which inhibits heat transfer between the carbon particles in the soot sample. However, when soot was mixed with $\mathrm{K} / \alpha-\mathrm{Al}_{2} \mathrm{O}_{3}$, the profile of the combustion peak changed markedly and was shifted to lower temperature, confirming current literature which shows that the presence of a potassium compound provides oxidation pathways with lower activation energy. ${ }^{33,35}$ 
A multiple peak in the dTG of $\mathrm{K} / \alpha-\mathrm{Al}_{2} \mathrm{O}_{3}$ and soot suggests that several soot oxidation processes may be taking place via different mechanisms. Comparison of TGA profiles of $\mathrm{K} / \alpha-\mathrm{Al}_{2} \mathrm{O}_{3}$ in the presence and absence of soot (Fig. 1b) showed that mass losses between 325 and $700{ }^{\circ} \mathrm{C}$ are exclusively associated with soot and not catalyst decomposition. Therefore, the onset of the first soot oxidation event can be shown to occur at ca. 325-350 ${ }^{\circ} \mathrm{C}$. Such low onset temperatures for soot oxidation are in line with those previously reported by Matarrese et al. of 300-350 ${ }^{\circ} \mathrm{C} .{ }^{33}$ These initial soot oxidation tests confirmed, therefore, that this $\mathrm{K} / \alpha-\mathrm{Al}_{2} \mathrm{O}_{3}$ formulation has potential for application in a catalytic soot filter for the passive control of particulate on diesel passenger cars, where the exhaust-gas temperature rarely exceeds $350{ }^{\circ} \mathrm{C}$. The main oxidation process for $\mathrm{K} / \alpha-\mathrm{Al}_{2} \mathrm{O}_{3}$ occurred at $540{ }^{\circ} \mathrm{C}, 100{ }^{\circ} \mathrm{C}$ lower than for $\alpha-\mathrm{Al}_{2} \mathrm{O}_{3}$. An indication of the rate of reaction can be determined from the magnitude of dTG peaks, with the maximum rate of soot decomposition between $\alpha-\mathrm{Al}_{2} \mathrm{O}_{3}$ and main feature in $\mathrm{K} / \alpha-\mathrm{Al}_{2} \mathrm{O}_{3}$ being comparable, despite the difference in reaction temperature. TGA analysis also showed a mass loss event starting at 700-750 ${ }^{\circ} \mathrm{C}$ in the catalyst-containing sample, contributing to a loss of $2.5 \%$ of sample mass, which could be attributed to either the volatilisation of a potassium compound or its decomposition. TGA/DTA analysis of bulk $\mathrm{K}_{2} \mathrm{CO}_{3}$ shows that it decomposes at $900{ }^{\circ} \mathrm{C}$, the maximum temperature of our experiment, suggesting that the observed mass loss from $750{ }^{\circ} \mathrm{C}$ is predominantly due to volatilisation. ${ }^{39}$

XRD patterns of $\alpha-\mathrm{Al}_{2} \mathrm{O}_{3}$ and $\mathrm{K} / \alpha-\mathrm{Al}_{2} \mathrm{O}_{3}$, both before and after soot oxidation (Fig. S1, ESI $\dagger$ ) show reflections associated with $\alpha-\mathrm{Al}_{2} \mathrm{O}_{3}$. Fresh $\mathrm{K} / \alpha-\mathrm{Al}_{2} \mathrm{O}_{3}$ had additional reflections, attributed to $\mathrm{KHCO}_{3}$ and hydrated $\mathrm{K}_{2} \mathrm{CO}_{3} \cdot x \mathrm{H}_{2} \mathrm{O}$, which are no longer present after reaction. A series of broad ill-defined reflections that could not be attributed to any anticipated crystalline potassium carbonate or hydroxide phases were present post reaction. Potentially, these reflections could be associated with trace formation of potassium aluminate phases and $\mathrm{K} \beta-\mathrm{Al}_{2} \mathrm{O}_{3}$ which have been shown to form between 800-1000 ${ }^{\circ} \mathrm{C} .{ }^{40}$ Although potassium aluminate phases are reported to be unstable in the presence of atmospheric moisture and phase separate within days. ${ }^{41}$ The loss of crystalline $\mathrm{K}_{2} \mathrm{CO}_{3}$ could be due a range of single or multiple causes; namely, the decomposition of the carbonate to an alternative poorly crystalline compound, the formation of $\mathrm{K} \beta-\mathrm{Al}_{2} \mathrm{O}_{3}$, dispersion of the $\mathrm{K}_{2} \mathrm{CO}_{3}$ across the $\mathrm{Al}_{2} \mathrm{O}_{3}$ surface to form non-crystalline surface species or sufficient volatilisation to remove potassium species from the catalyst entirely.

XPS of $\mathrm{K} / \alpha-\mathrm{Al}_{2} \mathrm{O}_{3}$ and $\alpha-\mathrm{Al}_{2} \mathrm{O}_{3}$ both before and after use for soot oxidation can help determine if the potassium species has changed during reaction and/or is being lost from the $\mathrm{Al}_{2} \mathrm{O}_{3}$ surface. Quantification of surface composition as determined by XPS (Table 1) showed that for both materials there are signals associated with $\mathrm{K}, \mathrm{Al}, \mathrm{C}$ and $\mathrm{O}$ in addition to $\mathrm{Na}^{+}$ impurity in the support. After reaction, the $\mathrm{Na}^{+}$surface concentration increased due to the migration from the bulk structure of the support to the surface. On bare $\alpha-\mathrm{Al}_{2} \mathrm{O}_{3}$ the presence of carbon is due to adventitious surface adsorbed species.
Table 1 Elemental surface composition of catalysts before and after soot oxidation from XPS

\begin{tabular}{llllll}
\hline & \multicolumn{4}{l}{$\begin{array}{l}\text { Concentration based on XPS } \\
\text { peak area (at\%) }\end{array}$} \\
\cline { 2 - 6 } Sample & $\mathrm{Na}(1 \mathrm{~s})$ & $\mathrm{O}(1 \mathrm{~s})$ & $\mathrm{C}(1 \mathrm{~s})$ & $\mathrm{Al}(2 \mathrm{~s})$ & $\mathrm{K}\left(2 \mathrm{p}_{3 / 2}\right)$ \\
\hline $\mathrm{K} / \alpha-\mathrm{Al}_{2} \mathrm{O}_{3}$ & 0.1 & 58.1 & 20.4 & 27.4 & 4.0 \\
$\mathrm{~K} / \alpha-\mathrm{Al}_{2} \mathrm{O}_{3}$ after soot oxidation & 0.1 & 46.1 & 33.3 & 13.0 & 7.4 \\
$\alpha-\mathrm{Al}_{2} \mathrm{O}_{3}$ & 0.1 & 42.2 & 33.1 & 24.7 & - \\
$\alpha-\mathrm{Al}_{2} \mathrm{O}_{3}$ after soot oxidation & 2.5 & 45.3 & 27.1 & 25.1 & -
\end{tabular}

After reaction with soot, slight increases in $\mathrm{Al}$ and $\mathrm{O}$ concentrations and a decrease in carbon indicate that some of this adventitious carbon is lost during the reaction. In $\mathrm{K} / \alpha-\mathrm{Al}_{2} \mathrm{O}_{3}$ the $\mathrm{Al}$ surface concentration decreases by $50 \%$ after reaction with soot, along with a small decrease in $\mathrm{O}$, a corresponding increase in $\mathrm{C}$ and a $85 \%$ increase in the surface $\mathrm{K}$ concentration. These changes in surface concentration support the theory that a mobile potassium species has become dispersed over the $\mathrm{Al}_{2} \mathrm{O}_{3}$ during reaction, accounting for the decrease in $\mathrm{Al}$ and increase in $\mathrm{K}$. It further suggests that the formation of bulk potassium aluminate phases has not occurred to a significant extent, as a drop in surface potassium concentration would be expected, through its migration into the sample bulk. While, in the case of $\gamma-\mathrm{Al}_{2} \mathrm{O}_{3}$ surface potassium species can migrate deep into the pore network, using $\alpha-\mathrm{Al}_{2} \mathrm{O}_{3}$ ensures that this migration can be discounted.

Spectra from the $\mathrm{K} 2 \mathrm{p} / \mathrm{C} 1 \mathrm{~s}$ region of $\mathrm{K} / \alpha-\mathrm{Al}_{2} \mathrm{O}_{3}$, before and after soot oxidation, are shown in Fig. S2 (ESI $\dagger$ ). The positions of the $\mathrm{K} 2 \mathrm{p}_{1 / 2}$ and $\mathrm{K} 2 \mathrm{p}_{3 / 2}$ binding energies are comparable in both samples, at 292.5/292.7 eV and 295.2/295.5 eV, and match values reported in the literature, which was expected given that it is known to be insensitive to chemical environment. ${ }^{42}$ The C1s spectra of both samples were fitted with 3 peaks, 2 associated with adventitious carbon at 287.6 and $285.2 \mathrm{eV}$ and a peak at $c a$. $289 \mathrm{eV}$ attributed to a carbonate anion. Indeed, the C1s associated with carbonate in the fresh $\mathrm{K} / \alpha-\mathrm{Al}_{2} \mathrm{O}_{3}$ at $288.6 \mathrm{eV}$ is comparable with that observed by Kantschewa et al. for $\mathrm{K}_{2} \mathrm{CO}_{3} /$ $\gamma \mathrm{Al}_{2} \mathrm{O}_{3}$ at a binding energy of $289.6 \mathrm{eV}$ (when normalised to C1s). ${ }^{42}$ After reaction with soot, a notable shift in this C1s binding energy to $289.4 \mathrm{eV}$ was seen, which while still within the range anticipated for a carbonate species, indicates that the compound is not bulk $\mathrm{K}_{2} \mathrm{CO}_{3}$. The shift could, speculatively, be interpreted as being due to a reduction in particle size of $\mathrm{K}_{2} \mathrm{CO}_{3}$ on dispersion over the $\alpha-\mathrm{Al}_{2} \mathrm{O}_{3}$.

The $\mathrm{O} 1 \mathrm{~s}$ spectra for $\mathrm{K} / \alpha-\mathrm{Al}_{2} \mathrm{O}_{3}$ before and after use are shown in Fig. S3 (ESI $\dagger$ ). As noted previously by Kantschewa et al. the feature must comprise of multiple components, including $\mathrm{O}$ associated with carbonate, surface hydroxyl species and surface $\mathrm{O}^{2-}$ from $\mathrm{Al}_{2} \mathrm{O}_{3}{ }^{42}$ The authors attributed a O1s binding energy of $532 \mathrm{eV}$ to pure $\mathrm{K}_{2} \mathrm{CO}_{3}, 532.2 \mathrm{eV}$ to surface hydroxyl groups and $530.3 \mathrm{eV}$ to lattice oxygen in $\gamma-\mathrm{Al}_{2} \mathrm{O}_{3}$. Interestingly, the unfitted O1s spectra of $\mathrm{K} / \alpha-\mathrm{Al}_{2} \mathrm{O}_{3}$ shifted from $531.5 \mathrm{eV}$ to a higher binding energy of $521.5 \mathrm{eV}$ after reaction with soot, strongly indicating that the surface coverage of carbonate, relative to lattice oxygen has increased significantly.

In summary, findings from TGA, ex situ XRD and XPS provide initial understanding of the structural changes of potassium 
speciation before and after reaction. Crystalline and poorly dispersed $\mathrm{K}_{2} \mathrm{CO}_{3} \cdot x \mathrm{H}_{2} \mathrm{O}$ and $\mathrm{KHCO}_{3}$ are present on the fresh catalyst. Given that $\mathrm{KHCO}_{3}$ decomposes at ca. $150{ }^{\circ} \mathrm{C}$ it cannot have been within the catalyst directly on preparation, as the material was calcined to $500{ }^{\circ} \mathrm{C}$, but must have formed by exposure to atmospheric $\mathrm{CO}_{2}$ and $\mathrm{H}_{2} \mathrm{O}$ during storage of the catalyst. After reaction with soot, the surface concentration of potassium increased dramatically and can be attributed to being predominantly associated with a surface distributed potassium carbonate. TGA analysis also indicated that at above $750{ }^{\circ} \mathrm{C}$ potassium carbonate decomposition or volatilisation began. Clearly, the reactive potassium species are highly mobile at soot decomposition temperatures and aid soot-catalyst contact to the benefit of catalytic performance. The findings cannot, however, identify intermediate species present during the reaction or provide the detail required to correlate structural changes directly with catalytic properties. The sensitivity of alkali metal compounds to moisture and $\mathrm{CO}_{2}$ further suggest that species present ex situ may be quite different to those under reaction conditions. Hence, using these ex situ findings as a guide, an operando potassium K-edge XANES of $\mathrm{K} / \alpha-\mathrm{Al}_{2} \mathrm{O}_{3}$ during soot oxidation was performed.

\section{Operando potassium K-edge X-ray absorption spectroscopy}

Fig. 2 shows the potassium K-edge XANES spectra of $\mathrm{K} / \alpha-\mathrm{Al}_{2} \mathrm{O}_{3}$ at room temperature alongside potassium standards of carbonate compounds $\left(\mathrm{K}_{2} \mathrm{CO}_{3}\right.$ and $\left.\mathrm{KCHO}_{3}\right)$, a carboxylic acid $\left(\mathrm{KCH}_{3} \mathrm{CO}_{2}\right)$, the superoxide $\mathrm{KO}_{2}$ and a hydroxide compound $\left(\mathrm{KOH} \cdot x \mathrm{H}_{2} \mathrm{O}\right)$. Sugiura and Muramatsu provide one of the few XANES studies of an extensive range of potassium compounds reported in the literature. ${ }^{43}$ The authors, in conjunction with the work of Dutta and co-workers, ${ }^{44}$ assign potassium K-edge XANES features as follows; pre-edge features assigned to $\mathrm{K}^{+} 1 \mathrm{~s} \rightarrow 3 \mathrm{~d}$ and/or $1 \mathrm{~s} \rightarrow 4 \mathrm{~s}$ forbidden transitions (denoted bands $\mathrm{A}^{\mathrm{i}}$ and A respectively), the

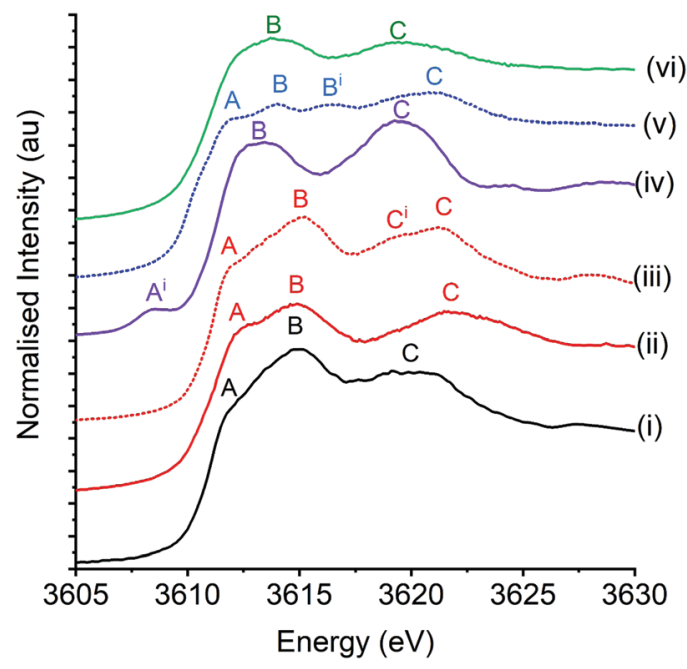

Fig. 2 Potassium $\mathrm{K}$-edge XANES of $\mathrm{K} / \alpha-\mathrm{Al}_{2} \mathrm{O}_{3}$ and standards. (i) $\mathrm{K} / \alpha-\mathrm{Al}_{2} \mathrm{O}_{3}$ (ii) $\mathrm{K}_{2} \mathrm{CO}_{3}$, (iii) $\mathrm{KHCO}_{3}$, (iv) $\mathrm{K}_{2} \mathrm{O}$, (v) $\mathrm{K}\left(\mathrm{CH}_{3} \mathrm{CO}_{2}\right.$ ) and (vi) $\mathrm{KOH} \cdot x \mathrm{H}_{2} \mathrm{O}$. Features; $A^{i}$ is $1 s \rightarrow 3 d, A$ is $1 s \rightarrow 4 s, B$ and $B^{i}$ is $1 s \rightarrow 4 d$ and $C / C^{i}$ is multiple scattering resonances. predominant $1 \mathrm{~s} \rightarrow 4 \mathrm{p}$ main transition (denoted band $\mathrm{B}$ ), which can split into two features under the influence of a crystal ligand field (denoted band $\mathrm{B}^{\mathrm{i}}$ ), and higher energy bands associated with multiple scattering processes (band $\mathrm{C}$ ). The first principles understanding, and assignment of these bands, is limited and based on atomic approaches, where the assumption is made that as potassium is highly ionic, ligand coordination can be treated by ligand fields. Despite this, the XANES of $\mathrm{K} / \alpha-\mathrm{Al}_{2} \mathrm{O}_{3}$, when simply compared with the potassium standards, most visibly matched that of $\mathrm{K}_{2} \mathrm{CO}_{3}$ and $\mathrm{KHCO}$, in broad agreement with ex situ XRD and XPS data.

The energy positions of the XANES features of $\mathrm{K} / \alpha-\mathrm{Al}_{2} \mathrm{O}_{3}$ with the $\mathrm{K}_{2} \mathrm{CO}_{3}$ and $\mathrm{KHCO}_{3}$ standards are shown in Table 2. The positioning in each material of features $\mathrm{A}$ and $\mathrm{B}$ were similar, with the catalyst's B feature being in between the $0.4 \mathrm{eV}$ difference seen for the two standards. However, the multiple scattering resonance band $\mathrm{C}$ was notably different between samples. The broad feature seen in $\mathrm{K} / \alpha-\mathrm{Al}_{2} \mathrm{O}_{3}$, which has been assigned as a single feature as opposed to two overlapping features, was $2.1 \mathrm{eV}$ lower in energy compared with $\mathrm{K}_{2} \mathrm{CO}_{3}$. Jacobs et al. reported shifts in the position of multiple scattering resonance features of $\mathrm{K}_{2} \mathrm{CO}_{3}$ dispersed on $\mathrm{SiO}_{2}$ compared to their bulk structures. ${ }^{20}$ The feature being sharper and at a higher energy in bulk compounds, compared to that seen in potassium compounds with reduced long-range order that are on a support. Therefore the $2.1 \mathrm{eV}$ decrease in position $\mathrm{C}$ seen in $\mathrm{K} / \alpha-\mathrm{Al}_{2} \mathrm{O}_{3}$ could be attributed to reduced long-range order of dispersed $\mathrm{K}_{2} \mathrm{CO}_{3}$, relative to bulk $\mathrm{K}_{2} \mathrm{CO}_{3}$. However, the conclusion that $\mathrm{K}_{2} \mathrm{CO}_{3}$ is simply dispersed on the $\mathrm{Al}_{2} \mathrm{O}_{3}$ surface is complicated by the clear evidence of crystalline $\mathrm{KHCO}_{3}$ and $\mathrm{K}_{2} \mathrm{CO}_{3} \cdot x \mathrm{H}_{2} \mathrm{O}$ in fresh $\mathrm{K} / \alpha-\mathrm{Al}_{2} \mathrm{O}_{3}$ from XRD. Specifically, this shows that a significant proportion of potassium species are in crystalline bulk state. Comparison between the XANES of $\mathrm{K} / \alpha-\mathrm{Al}_{2} \mathrm{O}_{3}$ and $\mathrm{KHCO}_{3}$ provides better agreement regarding the position of multiple scattering features, although the band is broader and at slightly lower energy in $\mathrm{K} / \alpha-\mathrm{Al}_{2} \mathrm{O}_{3}$. Therefore, it is suggested that a mixture of $\mathrm{KHCO}_{3}$ and domains and $\mathrm{K}_{2} \mathrm{CO}_{3} \cdot x \mathrm{H}_{2} \mathrm{O}$ account for the perceived lack of long-range order without it being highly dispersed over the $\alpha-\mathrm{Al}_{2} \mathrm{O}_{3}$ surface. Changes in the local $\mathrm{RuO}_{2}$ rutile structure on hydration have previously been seen in Ru K-edge XANES with a similar splitting of a broad feature into 2 clear peaks on dehydration. ${ }^{45}$ The observation is of clear importance when considering future potassium XANES experiments. The hygroscopic and reactive nature of potassium compounds under atmospheric conditions can result in the formation of alternative structures and can be confused or

Table 2 Position of features in potassium K-edge XANES

\begin{tabular}{llll}
\hline Sample & Band A $(1 \mathrm{~s} \rightarrow 3 \mathrm{~d})$ & Band B $(1 \mathrm{~s} \rightarrow 4 \mathrm{p})$ & Band C $(1 \mathrm{~s} \rightarrow \mathrm{CR})$ \\
\hline $\mathrm{K}_{2} \mathrm{CO}_{3}$ & 3612.4 (shoulder) & 3614.8 & 3622.0 \\
$\mathrm{KHCO}_{3}$ & 3612.1 (shoulder) & 3615.2 & $3619.8+3621.2$ \\
$\mathrm{~K} \alpha-\mathrm{Al}_{2} \mathrm{O}_{3}$ & 3612.4 (shoulder) & 3615.0 & $3619.9^{a}$
\end{tabular}

${ }^{a}$ Feature possibly two overlapping bands as seen in $\mathrm{KHCO}_{3}$. However, accurate position of each feature could not be determined and was treated as a single feature. 

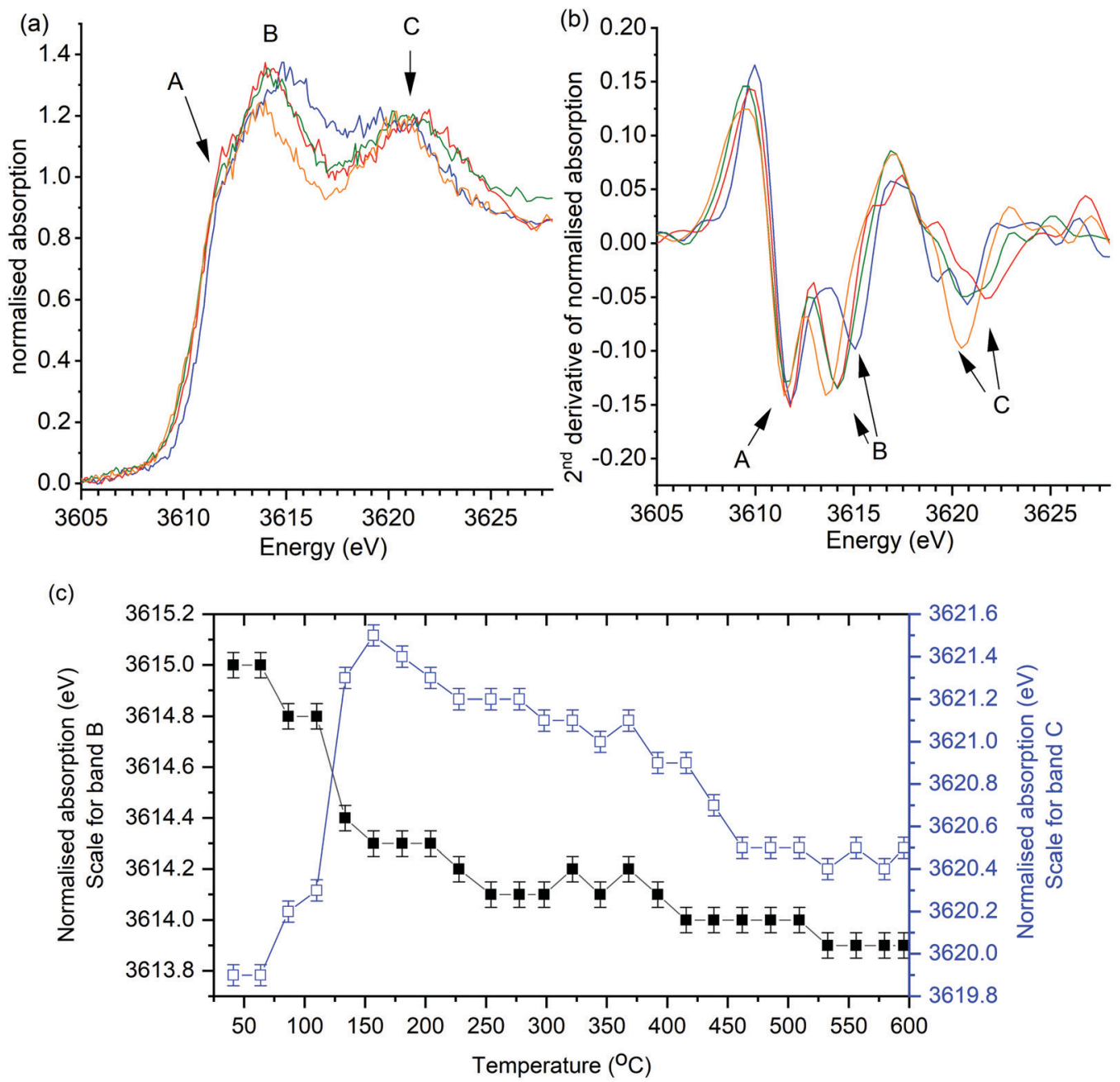

Fig. 3 Control operando potassium K-edge XANES of $\mathrm{K} / \alpha-\mathrm{Al}_{2} \mathrm{O}_{3}$ during heating to $600{ }^{\circ} \mathrm{C}$ in the absence of soot. Heating rate of $2{ }^{\circ} \mathrm{C}$ min ${ }^{-1}$ (a) Selection of normalised XANES data showing key changes in catalyst structure during reaction. (b) 2nd derivative of data processed XANES spectra shown in (a). XANES scan at; $40{ }^{\circ} \mathrm{C}$ (blue), $160{ }^{\circ} \mathrm{C}$ (red), $300{ }^{\circ} \mathrm{C}$ (green) and $600{ }^{\circ} \mathrm{C}$ (orange). Fig. $6 \mathrm{c}$ shows recorded energy of features B (1s $\rightarrow 4 \mathrm{~d}$ ) and $\mathrm{C}$ (multiple scattering feature) at all recorded temperatures. Error of $\pm 0.1 \mathrm{eV}$ determined as confidence in measuring peak maximum.

conflated with particle dispersion, if not combined with other characterisation techniques.

In the first operando experiment $\mathrm{K} / \alpha-\mathrm{Al}_{2} \mathrm{O}_{3}$ was heated in synthetic air $\left(20 \% \mathrm{O}_{2}\right.$ in $\left.\mathrm{He}\right)$ in the absence of soot as a control experiment, that showed observable changes in the position of XANES features on heating to $600{ }^{\circ} \mathrm{C}$ (Fig. 3). The relatively poor signal to noise observed in these operando experiments demonstrates the challenge of the low energy X-rays measurements through the reactor windows. Yet, while an improvement in signal to noise would be desirable, the peak positions and XANES features are clearly discernible. No new features were observed in the XANES but splitting of the B and $\mathrm{C}$ bands was observed. Changes in peak positions were confirmed from the 2nd derivatives of the data, which show that band A remained constant throughout experiments, while B and C shifted (Fig. 3b). The position of band B was found to shift from $3614.9 \mathrm{eV}$ to $3614.1 \mathrm{eV}$ on heating from room temperature to $250{ }^{\circ} \mathrm{C}$ and thereafter decreased marginally by a total of $0.2 \mathrm{eV}$ between 250 and $600{ }^{\circ} \mathrm{C}$ (Fig. 3c). Band C position was found to initially increase from $3619.9 \mathrm{eV}$ to a maximum of $3621.5 \mathrm{eV}$, on heating to $160{ }^{\circ} \mathrm{C}$. Further heating from $160{ }^{\circ} \mathrm{C}$ to $600{ }^{\circ} \mathrm{C}$ resulted in the multiple scattering peak slowly reducing in energy to $3620.4 \mathrm{eV}$.

The same general trend in the progression of band positions was observed in the operando XANES analysis of $\mathrm{K} / \alpha-\mathrm{Al}_{2} \mathrm{O}_{3}$ during soot combustion (Fig. 4). In the presence of soot, the shifting of band B was found to be comparable to heating in the absence of soot, with a significant decrease from $3615.0 \mathrm{eV}$ to $3614.2 \mathrm{eV}$ on heating to $150{ }^{\circ} \mathrm{C}$, followed by a relatively stable energy position thereafter. The progression of band $\mathrm{C}$ also followed the same trend as in the control experiment, although the decrease in band position on heating above $220{ }^{\circ} \mathrm{C}$ in the presence of soot was more rapid (Fig. 4c), with a sudden $0.5 \mathrm{eV}$ drop relative to the slow decline in energy seen in the control experiment.

Regarding correlation between potassium XANES features and structural changes of a sample during a catalytic reaction, there are only three published papers to aid our interpretation 

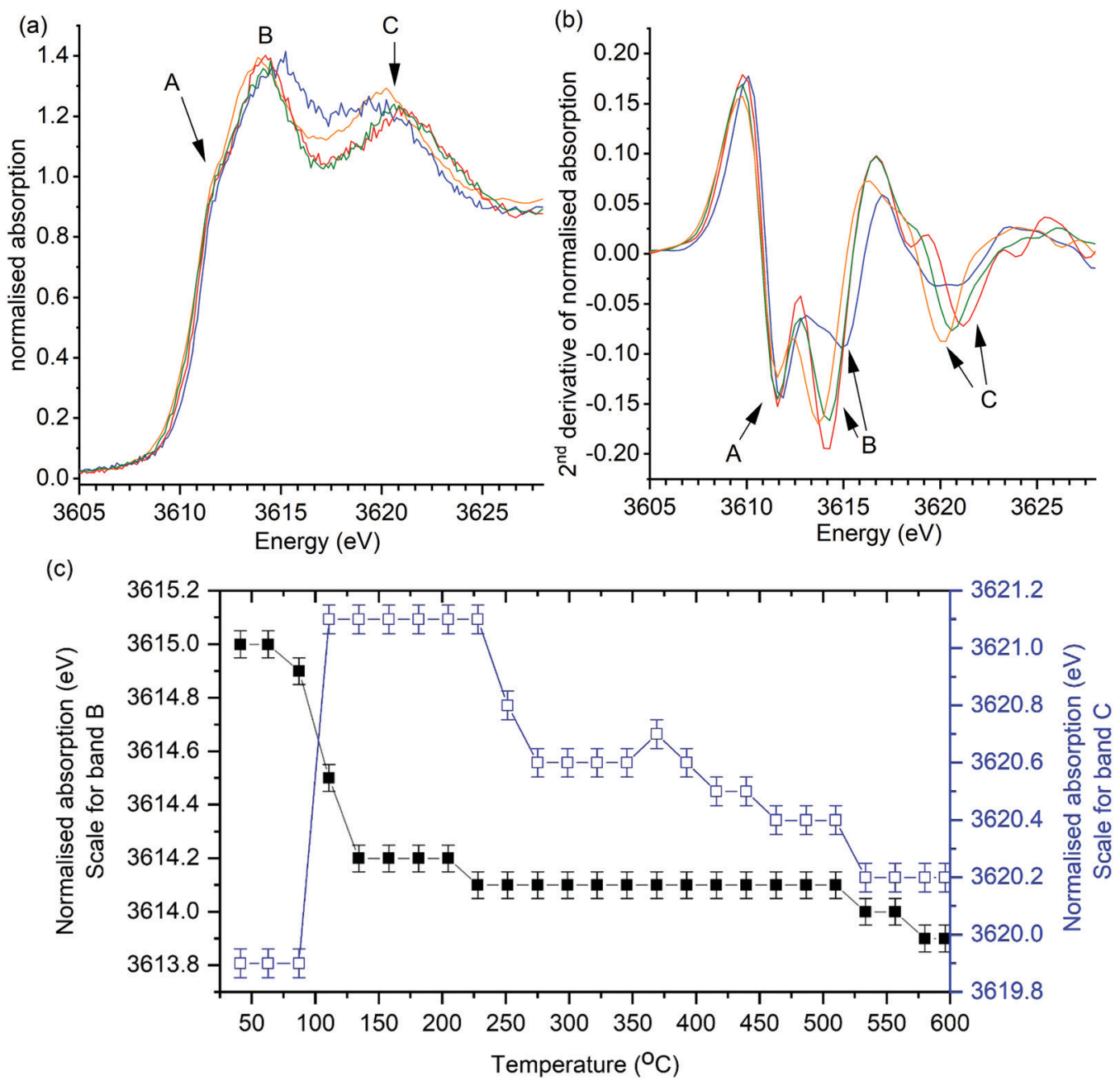

Fig. 4 Operando potassium K-edge XANES of $\mathrm{K} / \alpha-\mathrm{Al}_{2} \mathrm{O}_{3}$ during temperature programmed soot oxidation. Catalyst: soot ratio of $10: 1$. Heating rate of $2{ }^{\circ} \mathrm{C} \mathrm{min}^{-1}$. (a) Selection of normalised XANES data showing key changes in catalyst structure during reaction. (b) 2nd derivative of data processed XANES spectra shown in (a). XANES scan at; $40{ }^{\circ} \mathrm{C}$ (blue), $160{ }^{\circ} \mathrm{C}$ (red), $300{ }^{\circ} \mathrm{C}$ (green) and $600{ }^{\circ} \mathrm{C}$ (orange). Fig. $7 \mathrm{c}$ shows recorded energy of features $\mathrm{B}(1 \mathrm{~s} \rightarrow 4 \mathrm{~d}$ ) and $\mathrm{C}$ (multiple scattering feature) at all recorded temperatures. Error of $\pm 0.1 \mathrm{eV}$ determined as confidence in measuring peak maximum.

of the data. Jacobs et al. studied potassium promoted FischerTropsch catalysts ex situ, while Huffman et al. reported an in situ study of potassium XANES at $200{ }^{\circ} \mathrm{C}$ under different $\mathrm{H}_{2} /$ $\mathrm{CO} / \mathrm{CO}_{2}$ gas compositions and the decomposition of potassium containing lignite chars. ${ }^{20,24,25}$ A further complication is that these studies provide alternative hypothesis for observed changes in XANES features. As discussed above, changes in band $\mathrm{C}$ position have been attributed by Jacobs et al. as being due to changes in the long-range order of a compound $\left(\mathrm{K}_{2} \mathrm{CO}_{3}\right)$, due to their dispersion on support structures. ${ }^{20}$ Alternatively, Huffman/Huggins et al. associate changes in band $\mathrm{C}$ position as being due to evolution of different potassium compounds. ${ }^{24}$ Variation in band B, associated with the $1 \mathrm{~s} \rightarrow 4 \mathrm{p}$, is not discussed, with Jacobs et al. stating it remains fixed due to the simple nature of the electronic transition. However, the variations in position of features associated with the $1 \mathrm{~s} \rightarrow 4 \mathrm{p}$ transition, seen by Hung and Muramatsu's studies of potassium compounds and the standards reported in this study, show that changes in the local environment of $\mathrm{K}^{+}$do influence band $\mathrm{B}$ energy in the range of $2 \mathrm{eV}$.
Both effects discussed in the literature can be considered during the reaction of $\mathrm{K} / \alpha-\mathrm{Al}_{2} \mathrm{O}_{3}$ with soot and the control experiment; i.e., a change in the potassium compound during reaction, or a change in local structure of a given compound through dispersion/aggregation or crystallisation. Given there are no clear additional features associated with splitting of the $\mathrm{B}$ band or pre-edge $1 \mathrm{~s} \rightarrow 3 \mathrm{~d}$ features, the shifting of features $\mathrm{B}$ and $\mathrm{C}$ are difficult to assign to definitive changes in ligand environment around $\mathrm{K}^{+}$. Specifically, the absence of the distinctive $1 \mathrm{~s} \rightarrow 3 \mathrm{~d}$ seen in $\mathrm{KO}_{2}$ (band $\mathrm{A}^{1}$ in Fig. 2) suggest this proposed reactive species was not present to a significant extent during soot oxidation. Given the high loading of potassium within the catalyst and the transient nature of reactive species like $\mathrm{KO}_{2}$ the lack of characteristic XANES features for this species does not exclude its existence entirely but shows that it is not present as a stable resting state under reaction conditions. It can be noted that final positions of band $\mathrm{B}$ and $\mathrm{C}$ in $\mathrm{K} / \alpha-\mathrm{Al}_{2} \mathrm{O}_{3}$, on heating to $600{ }^{\circ} \mathrm{C}(3613.9$ and $3620.2 \mathrm{eV})$ are close to that recorded for $\mathrm{KOH} \cdot x \mathrm{H}_{2} \mathrm{O}$ at $3613.9 \mathrm{eV}$ and 
$3619.7 \mathrm{eV}$. However, assignment to $\mathrm{KOH}$ would not be made with confidence. Firstly, $\mathrm{K}^{+}$environment in $\mathrm{KOH}$ is highly distorted with a significant range of $\mathrm{K}-\mathrm{O}$ distances between 2.69 and $3.15 \AA^{46}{ }^{46}$ Additionally, it has a propensity to hydrate or react with carbon dioxide. $\mathrm{KOH} \cdot x \mathrm{H}_{2} \mathrm{O}$ is therefore less dependable as a descriptor of $\mathrm{K}-\mathrm{OH}$ interactions and perhaps more of an indicator of a disordered $\mathrm{K}^{+}$environment. Further, post reaction XPS showed that carbonate was present within the $\mathrm{K} / \alpha$ $\mathrm{Al}_{2} \mathrm{O}_{3}$ sample, suggesting literal assignment of the final XANES species to $\mathrm{KOH}$ is dubious. Clearly, the difficulty in assigning the observed XANES changes show the need for detailed XANES modelling to provide a more definitive understanding and assignment of specific structures. Therefore, results of the current study will initially be interpreted more generally as being due to changes in the local structure of $\mathrm{K}^{+}$; predominantly in the form of $\mathrm{K}_{2} \mathrm{CO}_{3}$ and $\mathrm{KHCO}_{3}$ as indicated by the similarity of the initial XANES spectra to potassium carbonates and the evidence from post reaction XPS. To measure this structural change, a simplistic indicator parameter, based on the difference in energy between bands $\mathrm{B}$ and $\mathrm{C}(\triangle \mathrm{CB})$ was determined. XANES modelling of $\mathrm{KHCO}_{3}$ and $\mathrm{K}_{2} \mathrm{CO}_{3}$ will then be considered to support these initial hypothesised structural changes.

Changes in C-B energy with respect to reaction temperature, for reactions with and without soot, are shown in Fig. 5 alongside the simultaneously recorded mass spectrometry of mass 44 $\left(\mathrm{CO}_{2}\right)$ and mass $18\left(\mathrm{H}_{2} \mathrm{O}\right)$. In the absence of soot, a notable increase in $\triangle \mathrm{CB}$ from $4.9(2) \mathrm{eV}$ to $7.2(2) \mathrm{eV}$ was seen between 60 and $160{ }^{\circ} \mathrm{C}$, which coincided with evolution of both $\mathrm{CO}_{2}$ and $\mathrm{H}_{2} \mathrm{O}$. In the presence of soot, a similar trend was observed but with a slightly smaller increase in $\Delta \mathrm{CB}$ to $6.9(2) \mathrm{eV}$. These spectroscopic observations are in agreement with those seen by Huggins et al. which was attributed as the conversion of a dispersed carboxyl-bond potassium species to $\mathrm{K}_{2} \mathrm{CO}_{3}$ on heating. ${ }^{25}$ The evolution of $\mathrm{H}_{2} \mathrm{O}$ and $\mathrm{CO}_{2}$ gases, monitored in the experiments reported in our paper are strongly suggestive of dehydration of $\mathrm{K}_{2} \mathrm{CO}_{3} \cdot x \mathrm{H}_{2} \mathrm{O}$ and $\mathrm{KHCO}_{3}$ decomposition to $\mathrm{K}_{2} \mathrm{CO}_{3}$ being reasonable for the notable increase in $\Delta \mathrm{CB}$. At $160{ }^{\circ} \mathrm{C}$ the $\Delta \mathrm{CB}$ of $7.2(2) \mathrm{eV}$ and $6.9(2) \mathrm{eV}$ is comparable to the $\mathrm{K}_{2} \mathrm{CO}_{3}$ standard $(7.1 \mathrm{eV})$, showing that that an ideal bulk $\mathrm{K}_{2} \mathrm{CO}_{3}$ is formed in both cases.

In the absence of soot, further heating to $415^{\circ} \mathrm{C}$ resulted in a slight decline in $\triangle \mathrm{CB}$ from 7.2(2) eV to 6.9(2) eV, with low levels of $\mathrm{CO}_{2}$ or $\mathrm{H}_{2} \mathrm{O}$ being detected by the mass spectrometer. The evolved gas observed during this blank was attributed to the oxidation of surface carbon species, as seen by XPS. This reduction in $\triangle \mathrm{CB}$ was dominated by a decrease in energy of band $\mathrm{C}$ (Fig. 3) and following Jacobs et al. hypothesis is attributed to the dispersion of $\mathrm{K}_{2} \mathrm{CO}_{3}$ over the alumina surface, as the potassium species become mobile. In the presence of soot, onset of $\mathrm{CO}_{2}$ and $\mathrm{H}_{2} \mathrm{O}$ formation began at $250{ }^{\circ} \mathrm{C}$ and was attributed to the oxidation of specific soot functional groups in close contact with the catalyst. Interestingly, a decrease in $\Delta \mathrm{CB}$, from $7.0(2) \mathrm{eV}$ to $6.5(2) \mathrm{eV}$, was observed at comparable temperatures $\left(230-270{ }^{\circ} \mathrm{C}\right)$ in the soot containing experiment. While relatively subtle, this change is notably different to the gradual decrease in $\Delta \mathrm{CB}$ seen in the absence of soot. The (a)
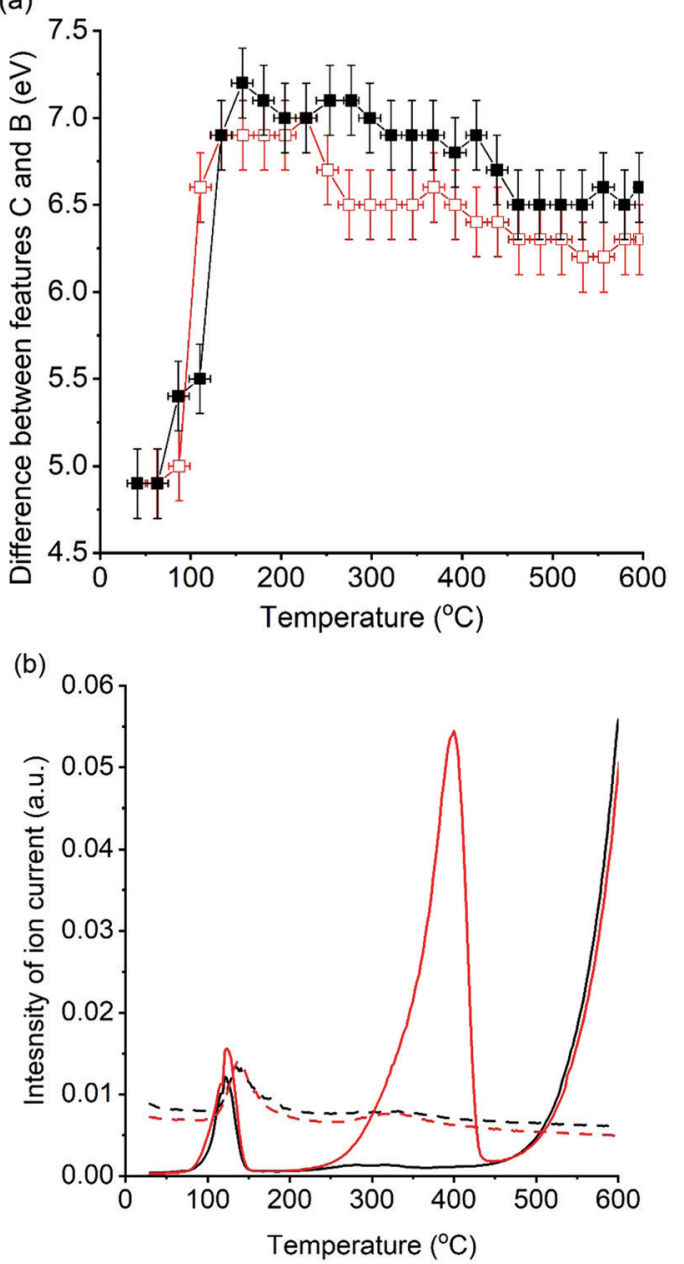

Fig. 5 Comparison of changes in potassium XANES features with recorded gas evolution for $\mathrm{K} / \alpha-\mathrm{Al}_{2} \mathrm{O}_{3}$ during temperature programmed soot oxidation. Control experiment in the absence of soot (black) and during soot oxidation (red). (a) Difference between XANES features $C$ and $B$ with respect to temperature. Estimated confidence error of $\pm 0.2 \mathrm{eV}$ determined from sum of measurement errors for energies of features $B$ and $C$. (b) Evolved gas analysis of $\mathrm{CO}_{2}$ (solid line) and $\mathrm{H}_{2} \mathrm{O}$ (dotted line).

significant drop in $\triangle \mathrm{CB}$ in the presence of soot was repeatable in a duplicate experiment (Fig. S4, ESI $\dagger$ ). Between $225^{\circ} \mathrm{C}$ and $450{ }^{\circ} \mathrm{C} \Delta \mathrm{CB}$ values were markedly lower in the soot containing experiment and coincided with the temperature range that $\mathrm{CO}_{2}$ evolution was observed $\left(250-440{ }^{\circ} \mathrm{C}\right)$. These findings show that the local structure of potassium changes during the catalytic oxidation of soot. The cause of this structural change with the onset of soot oxidation can be speculatively attributed to; (1) enhanced mobility of $\mathrm{K}_{2} \mathrm{CO}_{3}$ facilitated by the local exotherm generated by soot oxidation, i.e. observing the effect of soot combustion on the average structure of $\mathrm{K}_{2} \mathrm{CO}_{3}$ in the catalyst. (2) The formation of defects in the $\mathrm{K}_{2} \mathrm{CO}_{3}$ lattice caused by the formation of "active" potassium oxide centres, or an increased proportion of disordered active species in interaction with the soot. In either case, there is a small but discernible structurereactivity relationship observed for the first-time by using operando potassium K-edge XANES. 
Heating from $415{ }^{\circ} \mathrm{C}$ to $600{ }^{\circ} \mathrm{C}$ resulted in a further decrease $\Delta \mathrm{CB}$ in the control experiment from $6.9(2) \mathrm{eV}$ to a stable value of 6.5(2) eV by $460{ }^{\circ} \mathrm{C}$, indicating further potassium mobility and loss of long-range order through dispersion. In the presence of soot $\Delta \mathrm{CB}$ remained relatively constant with a slight $0.2 \mathrm{eV}$ drop to a final value of $6.3(2) \mathrm{eV}$, suggesting that soot combustion had assisted in lower temperature dispersion of the $\mathrm{K}_{2} \mathrm{CO}_{3}$, which was then in a pre-dispersed state during further heating. In both experiments $\mathrm{CO}_{2}$ formation was observed from $450{ }^{\circ} \mathrm{C}$. The production of $\mathrm{CO}_{2}$ at these temperatures, in the absence of soot, can be attributed to the initial decomposition of the graphitic windows of the reaction cell. Although there is no direct contact between the $\mathrm{K} / \alpha-\mathrm{Al}_{2} \mathrm{O}_{3}$ catalyst and the window, potassium species are clearly highly mobile and have facilitated graphite combustion. Given the unstable nature of the reactor cell windows above $600{ }^{\circ} \mathrm{C}$ it was not possible to study the high temperature changes seen by TGA at $c a .750{ }^{\circ} \mathrm{C}$. Although, given that soot oxidation was complete by $600{ }^{\circ} \mathrm{C}$, the use of XANES to study the influence of potassium local structure was not compromised. The final $\Delta \mathrm{CB}$ values are considerably greater than seen in the fresh catalyst, but lower than that of bulk $\mathrm{K}_{2} \mathrm{CO}_{3}$ with a value of $7.1 \mathrm{eV}$, showing that the local structure of potassium species is highly dynamic during heating.

\section{Potassium K-edge XANES simulation: influence of $\mathrm{KHCO}_{3}$ and $\mathrm{K}_{2} \mathrm{CO}_{3}$ local structure}

XANES spectra of $\mathrm{KHCO}_{3}$ and $\mathrm{K}_{2} \mathrm{CO}_{3}$ were simulated using FEFF9 with cluster sizes varying from 6-233 atoms or 6-50 atoms, for $\mathrm{K}_{2} \mathrm{CO}_{3}$ and $\mathrm{KHCO}_{3}$ respectively. The potassium environment (Fig. S5, ESI $\dagger$ ) for $\mathrm{KHCO}_{3}$ is 7 coordinate to oxygen, while two equally weighted environments of 9 (K1) and 6 (K2) coordinate are seen in $\mathrm{K}_{2} \mathrm{CO}_{3}$. Each potassium environment in $\mathrm{K}_{2} \mathrm{CO}_{3}$ was studied separately, with the influence of cluster size of the K1 component on the XANES shown in Fig. S6 and of the K2 component in Fig. S7 (ESI $\dagger$ ). For both environments at 6 atom cluster sizes the XANES comprised of two broad features at 3615 and $3621-3623 \mathrm{eV}$, with a third scattering feature observable at $3642 \mathrm{eV}$. As the cluster sizes were increased the broad feature at $3621-3623 \mathrm{eV}$ split into two features, identified as being the $\mathrm{B}$ and $\mathrm{C}$ bands discussed in the literature (vide supra). The presence of the A feature also becomes clear as the cluster size is increased. Fig. 6 shows the average XANES spectra of the 1:1 K1:K2 environments found in $\mathrm{K}_{2} \mathrm{CO}_{3}$ at cluster sizes representative of these changes, namely 6, 22, 121 and 223 atoms (full cluster size data set shown in Fig. S8, ESI $\dagger$ ), alongside the experimental XANES of $\mathrm{K}_{2} \mathrm{CO}_{3}$ and the $\mathrm{K} / \alpha-\mathrm{Al}_{2} \mathrm{O}_{3}$ catalyst. Excellent agreement between the energies of the simulated larger clusters (121 and 223 atoms) and experimentally obtained XANES of $\mathrm{K}_{2} \mathrm{CO}_{3}$ was observed (Table S1, ESI $\dagger$ ), intensities of features were not well reproduced as commonly seen for XANES modelling, that also does not include structural and thermal disorder effects.

The lack of identifiable $\mathrm{B}$ and $\mathrm{C}$ features at 6 atom cluster size is not observed experimentally in $\mathrm{K} / \alpha-\mathrm{Al}_{2} \mathrm{O}_{3}$ both ex situ or at any point during the operando experiments, suggesting such isolated species are not present. In simulation cluster sizes of

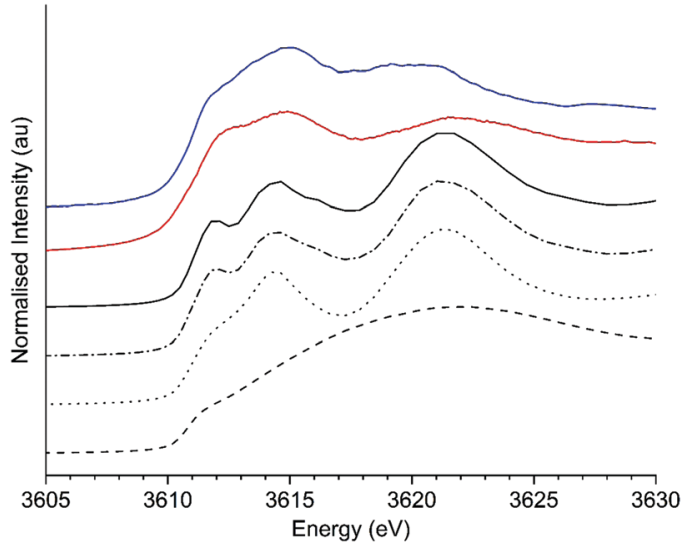

Fig. 6 Comparison of simulated potassium edge XANES of $\mathrm{K}_{2} \mathrm{CO}_{3}$ (both environments) at different cluster sizes with experimental $\mathrm{K}_{2} \mathrm{CO}_{3}$ and $\mathrm{K} / \alpha-\mathrm{Al}_{2} \mathrm{O}_{3}$. Black lines: 6 atoms (dashed), 22 atoms (dotted), 121 atoms (dashed-dotted) and 223 atoms (solid). Red line: experimental $\mathrm{K}_{2} \mathrm{CO}_{3}$ and blue line $\mathrm{K} / \alpha-\mathrm{Al}_{2} \mathrm{O}_{3}$.

22 and $>121$ atoms the features $\mathrm{B}$ and $\mathrm{C}$ are clearly present, but with feature $\mathrm{B}$ being at lower energy in the 22 atom simulation, at $3614.3 \mathrm{eV}$ vs. $3614.5 \mathrm{eV}$ in larger clusters, and feature $\mathrm{C}$ also shifted $0.2 \mathrm{eV}$ higher than seen in the larger cluster. The shift in $B$ feature position seen experimentally in $\mathrm{K} / \alpha-\mathrm{Al}_{2} \mathrm{O}$ from $3614.9 \mathrm{eV}$ to $3614.0 \mathrm{eV}$ could therefore reflect the formation of smaller clusters. The $\Delta \mathrm{CB}$ for the 22 atom cluster was $7.1 \mathrm{eV}, 0.4 \mathrm{eV}$ higher than in the larger cluster. Although a change in $\Delta \mathrm{CB}$ was seen by simulation it was found to be opposite, i.e. greater $\Delta \mathrm{CB}$ for small particles, to that seen experimentally and proposed by Jacobs. Therefore, it was concluded that simply altering cluster size did not sufficiently replicate experimental findings.

As discussed vide supra, $\mathrm{K} / \alpha-\mathrm{Al}_{2} \mathrm{O}_{3}$ at room temperature contained significant amounts of $\mathrm{KHCO}_{3}$. Therefore, the XANES spectra of this compound were simulated for clusters between 6-50 atoms in size (Fig. 7). Features simulated for clusters of 50 atoms broadly correlated with experimentation,

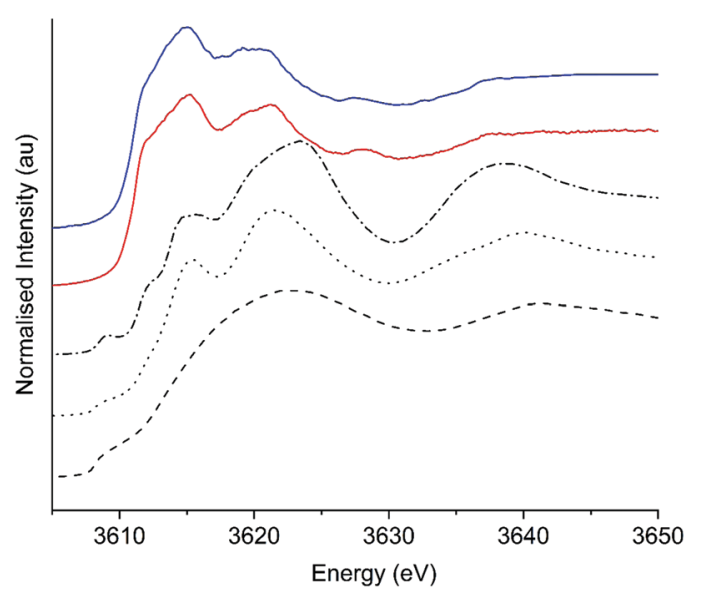

Fig. 7 Comparison of simulated potassium edge XANES of $\mathrm{KHCO}_{3}$ at different cluster sizes with experimental $\mathrm{KHCO}_{3}$ and $\mathrm{K} / \alpha-\mathrm{Al}_{2} \mathrm{O}_{3}$. Black lines: 6 atoms (dashed), 22 atoms (dotted), 50 atoms (dashed-dotted) Red line: experimental $\mathrm{KHCO}_{3}$ and blue line $\mathrm{K} / \alpha-\mathrm{Al}_{2} \mathrm{O}_{3}$. 
but with significant discrepancy in the position of bands $\mathrm{C}$ and $\mathrm{C}^{\mathrm{i}}$ which was at significantly higher energy in simulation. The 22 atom cluster reproduced the experimental energy of band $\mathrm{C}$ better with a $\Delta \mathrm{CB}$ value of $6.1 \mathrm{eV}$, which is notably smaller than the $6.8 \mathrm{eV}$ seen by simulation and experiment for $\mathrm{K}_{2} \mathrm{CO}_{3}$. At $<22$ atom cluster simulations were comparable with those for $\mathrm{K}_{2} \mathrm{CO}_{3}$; while not seen during the currently reported operando study, similar spectra were observed by Huggins et al. for potassium within a lignate structure. ${ }^{25}$ The simulations suggest that the species observed could be isolated small potassium compound clusters. Further simulation studies across a range of potassium compounds are required to verify how well the 6 atom cluster simulations for $\mathrm{KHCO}_{3} / \mathrm{K}_{2} \mathrm{CO}_{3}$ translate to other compounds. In summary simulation of $\mathrm{KHCO}_{3}$ reproduced the reduced $\triangle \mathrm{CB}$ experimentally only in the 22 atom cluster, with the divergence from experiment at larger cluster size raising concern over the validity of the simulation.

Two further strategies were employed in the simulation of $\mathrm{K}_{2} \mathrm{CO}_{3}$ XANES to support the operando study. Firstly, the expansion or contraction of the $\mathrm{K}_{2} \mathrm{CO}_{3}$ lattice by $5 \%$ was simulated, to reflect interaction with the $\alpha-\mathrm{Al}_{2} \mathrm{O}_{3}$ support or the reported expansion with high $\theta$ coverage of water. Models for each $\mathrm{K}$ site

(a)

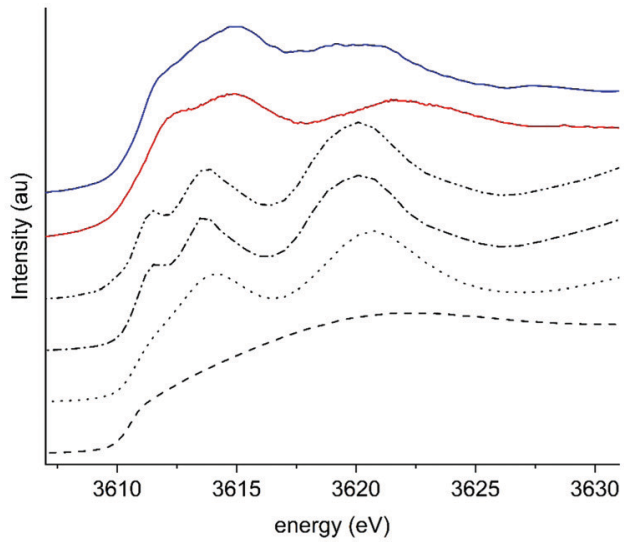

(b)

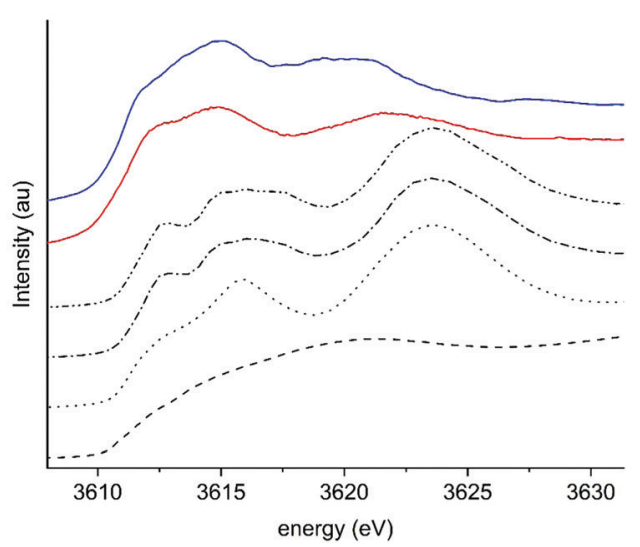

Fig. 8 Comparison of simulated potassium edge XANES of $\mathrm{K}_{2} \mathrm{CO}_{3}$ at different cluster sizes with $5 \%$ expansion/contraction of the lattice. (a) 5\% lattice expansion. (b) 5\% lattice contraction. Black lines: 6 atoms (dashed), 22 atoms (dotted), 50 atoms (dashed-dotted). Red line: experimental $\mathrm{K}_{2} \mathrm{CO}_{3}$ and blue line $\mathrm{K} / \alpha-\mathrm{Al}_{2} \mathrm{O}_{3}$. at the full range of cluster sizes are shown in Fig. S7-S11 (ESI $\dagger$ ). As seen in Fig. S11, expansion of the lattice resulted in a lowering of the energy position of the simulated XANES, contraction conversely shifted energies higher. The $\triangle \mathrm{CB}$ values show (Table S1, ESI $\dagger$ ) a change on expansion or contraction, with expansion giving a $\triangle \mathrm{CB} 6.3 \mathrm{eV}$ for the 223 atom cluster and a $\Delta \mathrm{CB}$ of $7.4 \mathrm{eV}$ on contraction of the same cluster. As clearly shown in Fig. 5a, during operando soot oxidation the shift in features $\mathrm{B}$ and $\mathrm{C}$ in $\mathrm{K} / \alpha-\mathrm{Al}_{2} \mathrm{O}_{3}$ were between 7.0 and $6.5 \mathrm{eV}$, which is within a similar range to that seen in these simulations. Importantly, while in simulation both bands $\mathrm{B}$ and $\mathrm{C}$ shifted, experimentally $\Delta \mathrm{CB}$ was influenced above $200{ }^{\circ} \mathrm{C}$ predominantly by shifts in band $\mathrm{C}$. Hence, while simulation did replicate $\Delta \mathrm{CB}$ changes, shifts were more symmetric in nature than observed experimentally (Fig. 8).

The second simulation strategy considered the potential for the $\mathrm{K} 1: \mathrm{K} 2$ environment ratio to alter during reaction, due to particle size effects or the formation of structural defects. Systematic variation of the K1:K2 ratio, shown in Fig. 9, demonstrates that such a variation can alter the relative positions of bands B and C. For K1:K2 extremes of $10: 90$ and $90: 10$ the

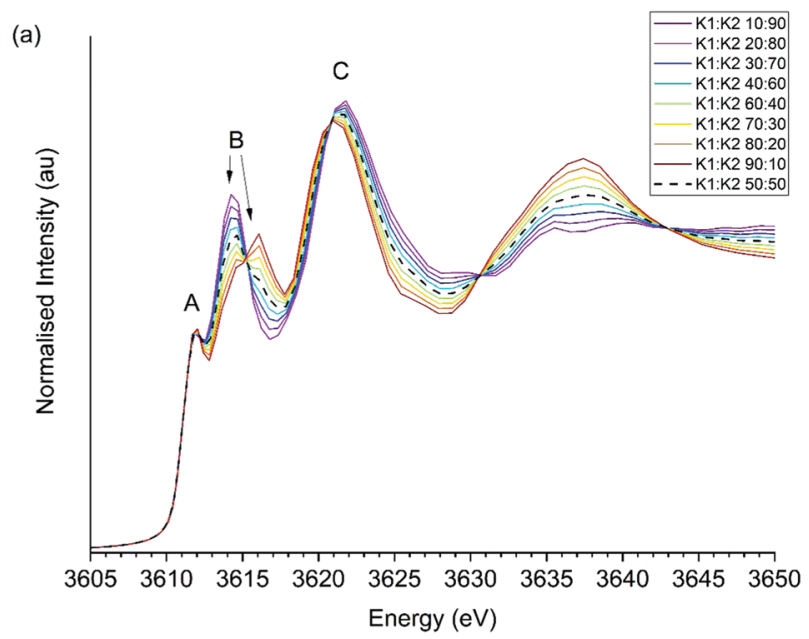

(b)

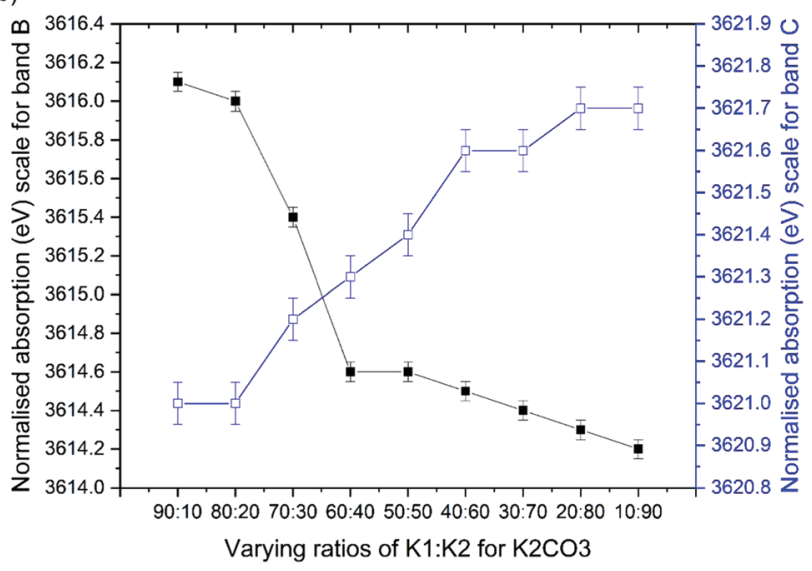

Fig. 9 Influence of $\mathrm{K} 1$ : $\mathrm{K} 2$ ratio on simulated XANES spectra of $\mathrm{K}_{2} \mathrm{CO}_{3}$. (a) Simulated XANES, (b) position of observed bands B and C. 
$\Delta \mathrm{CB}$ values were calculated to be 4.9 and $7.5 \mathrm{eV}$. These differences are comparable to the observed changes in experimental $\Delta \mathrm{CB}$ values from 7.0 and $6.5 \mathrm{eV}$ Although, experimentally band $\mathrm{C}$ was observed to drop at high temperatures while $\mathrm{B}$ remained constant, which is not reflected in simultaneous reduction of $\mathrm{B}$ and increase in $\mathrm{C}$ band energy in simulation.

Therefore, it can be concluded that current simulations provide a rationale for the changes in XANES features observed experimentally. However, no single set of experiments precisely replicated experimental observation. Generally, the simulations support the hypothesis that the fresh catalyst comprises of a potassium environment inconsistent with bulk $\mathrm{K}_{2} \mathrm{CO}_{3}$. Practically, this is most likely due to the presence of $\mathrm{KHCO}_{3}$ that is only partially substantiated in the simulations at a specific cluster size. Further, heating above the decomposition of the $\mathrm{KHCO}_{3}$ resulted in shifts in band $\mathrm{C}$ which couldn't be directly replicated by simulation. Yet, simulation clearly demonstrated that structural changes in $\mathrm{K}_{2} \mathrm{CO}_{3}$ can influence the positions of features B and C.

\section{Conclusion}

Operando potassium K-edge XANES has been used to study the evolution of potassium species in the catalytic oxidation of soot. The experiment is, to our knowledge, the first reported XANES operando study at a potassium K-edge and demonstrates the potential for further XANES analysis of alkali and alkaline earth catalysts, promotors and poisons, during reaction. Two identifiable phenomena were observed during the temperature programmed oxidation experiments. Firstly, significant changes in the potassium XANES occurred during the dehydration and decomposition of bicarbonate, between 100-160 ${ }^{\circ} \mathrm{C}$, to produce bulk $\mathrm{K}_{2} \mathrm{CO}_{3}$. The result provides a note of caution when interpreting potassium XANES; namely that the spectra are highly sensitive to local structure, which is itself sensitive to hydration and adsorption of $\mathrm{CO}_{2}$. This sensitivity is further confirmed by XANES simulations which showed changes in cluster size, expansion or contraction of the lattice, and changes in the different abundance of potassium crystallographic environment significantly changed simulated XANES spectra of $\mathrm{K}_{2} \mathrm{CO}_{3}$. At higher temperatures of $200-600{ }^{\circ} \mathrm{C} \mathrm{K}_{2} \mathrm{CO}_{3}$ becomes mobile and disperses over the $\mathrm{Al}_{2} \mathrm{O}_{3}$ support, as evidenced by progressive shifting of a feature in the XANES associated with multiple scattering resonance to lower energy. This finding is supported by XPS and XRD analysis of the catalyst post reaction. In the presence of soot, this change in XANES feature is significantly more pronounced than in a control experiment without soot and demonstrates interaction between potassium species and soot during its combustion. Simultaneously recorded mass spectroscopy showed that this change in XANES was co-current with the onset of soot oxidation. Current simulations could not model shifts in the purported multiple scattering feature to changes in lattice size or cluster size. However, changes in the ratio of the two potassium sites in $\mathrm{K}_{2} \mathrm{CO}_{3}$ did result in such a change. Although the explicit nature of this interaction is unresolved, it appears to exclude the possibility of the stoichiometric reaction of potassium carbonate with elemental carbon in the soot as a key step in the reaction mechanism. Instead, the alkali metal appears to have the classic catalytic role of activating $\mathrm{O}_{2}$ into reactive oxygen species, with the mobility of $\mathrm{K}_{2} \mathrm{CO}_{3}$ facilitating the transport of these species to immobilised soot particles. This represents a significant finding that can be investigated further, both for this specific example of soot oxidation, and in the broader context of other alkali promotors/poisons in a range of catalytic processes. Finally, the important role of simulation in ongoing studies is clearly highlighted.

\section{Conflicts of interest}

There are no conflicts to declare.

\section{Acknowledgements}

We acknowledge the EPSRC-funded XMaS Mid-Range facility at BM28 in the European Synchrotron Radiation Facility (ESRF), Grenoble, France where the XAFS measurements were performed (28-01-1223). We thank the XMaS beamline team for support of BM28 experiments. We acknowledge the X-ray absorption measurement time provided at the Diamond Light Source on B18 (SP19850). We also acknowledge the Environment theme of the UK Catalysis Hub (EPSRC grant EP/K014854/1). Alex Mayer thanks Diamond Lightsource for PhD funding. Dr Laurence Bouchenoire and Prof. K.G. Upul Wijaynatha are thanked for their time and support.

\section{References}

1 Z. Kowalczyk, S. Jodzis, W. Rarog, J. Zielinski and J. Pielaszek, Effect of potassium and barium on the stability of a carbon-supported ruthenium catalyst for the synthesis of ammonia, Appl. Catal., A, 1998, 173, 153-160.

2 D. R. Strongin and G. A. Somorjai, Effects of potassium on ammonia synthesis over iron single-crystal surfaces, J. Catal., 1988, 109, 51-60.

3 K. Aika, H. Hori and A. Ozaki, Activation of nitrogen by alkali metal promoted transition metal. I. Ammonia synthesis over ruthenium promoted by alkali metal, J. Catal., 1972, 27, 424-431.

4 D. B. Bukur, D. Mukesh and S. A. Patel, Promoter effects on precipitated iron catalysts for Fischer-Tropsch synthesis, Ind. Eng. Chem. Res., 1990, 29, 194-204.

5 V. R. R. Pendyala, U. M. Graham, G. Jacobs, H. H. Hamdeh and B. H. Davis, Fischer-Tropsch Synthesis: Deactivation as a Function of Potassium Promoter Loading for Precipitated Iron Catalyst, Catal. Lett., 2014, 144, 1704-1716.

6 M. Akimoto and E. Echigoya, Participation of double bond type lattice oxygen in vapor-phase catalytic oxidation of olefins, J. Catal., 1974, 35, 278-288. 
7 L. Chen, J. Li and M. Ge, The poisoning effect of alkali metals doping over nano $\mathrm{V}_{2} \mathrm{O}_{5}-\mathrm{WO}_{3} / \mathrm{TiO}_{2}$ catalysts on selective catalytic reduction of $\mathrm{NO}_{x}$ by $\mathrm{NH}_{3}$, Chem. Eng. J., 2011, 170, 531-537.

8 S. A. Kondrat, P. J. Smith, J. H. Carter, J. S. Hayward, G. J. Pudge, G. Shaw, M. S. Spencer, J. K. Bartley, S. H. Taylor and G. J. Hutchings, The effect of sodium species on methanol synthesis and water-gas shift $\mathrm{Cu} / \mathrm{ZnO}$ catalysts: Utilising high purity zincian georgeite, Faraday Discuss., 2017, 197, 287-307.

9 S. A. Kondrat, P. J. Smith, P. P. Wells, P. A. Chater, J. H. Carter, D. J. Morgan, E. M. Fiordaliso, J. B. Wagner, T. E. Davies, L. Lu, J. K. Bartley, S. H. Taylor, M. S. Spencer, C. J. Kiely, G. J. Kelly, C. W. Park, M. J. Rosseinsky and G. J. Hutchings, Stable amorphous georgeite as a precursor to a high-activity catalyst, Nature, 2016, 531, 83-87.

$10 \mathrm{~S}$. Wilke and M. H. Cohen, Influence of potassium adatoms on the dissociative adsorption of hydrogen on Pd(100), Surf. Sci., 1997, 380, L446-L454.

11 N. D. Lang, S. Holloway and J. K. Noerskov, Electrostatic adsorbate-adsorbate interactions: the poisoning and promotion of the molecular adsorption reaction, Surf. Sci., 1985, 150, 24-38.

12 P. J. Feibelman and D. R. Hamann, Electronic structure of a 'poisoned' transition-metal surface, Phys. Rev. Lett., 1984, 52, 61-64.

13 G. Pirug and H. P. Bonzel, Short range interaction of potassium and carbon monoxide coadsorbed on platinum(111), Surf. Sci., 1988, 199, 371-390.

14 J. E. Crowell and G. A. Somorjai, The effect of potassium on the chemisorption of carbon monoxide on the rhodium(111) crystal face, Appl. Surf. Sci., 1984, 19, 73-91.

15 Z.-P. Liu and P. $\mathrm{Hu}$, An Insight into Alkali Promotion: A Density Functional Theory Study of CO Dissociation on K/Rh(111), J. Am. Chem. Soc., 2001, 123, 12596-12604.

16 K. Nagase, T. Shimodaira, M. Itoh and Y. Zheng, Kinetics and mechanisms of the reverse Boudouard reaction over metal carbonates in connection with the reactions of solid carbon with the metal carbonates, Phys. Chem. Chem. Phys., 1999, 1, 5659-5664.

17 F. Kapteijn, O. Peer and J. A. Moulijn, Kinetics of the alkali carbonate catalyzed gasification of carbon. 1. Carbon dioxide gasification, Fuel, 1986, 65, 1371-1376.

18 D. W. McKee, Mechanisms of the alkali metal catalyzed gasification of coal, Fuel, 1983, 62, 170-175.

19 B. Lamontagne, F. Semond and D. Roy, K overlayer oxidation studied by XPS: the effects of the adsorption and oxidation conditions, Surf. Sci., 1995, 327, 371-378.

20 G. Jacobs, V. R. R. Pendyala, M. Martinelli, W. D. Shafer, M. K. Gnanamani, S. Khalid, A. MacLennan, Y. Hu and B. H. Davis, Fischer-Tropsch Synthesis: XANES Spectra of Potassium in Promoted Precipitated Iron Catalysts as a Function of Time On-stream, Catal. Lett., 2017, 147, 1861-1870.

21 F. Xu, Z. Huang, P. Hu, Y. Chen, L. Zheng, J. Gao and $\mathrm{X}$. Tang, The promotion effect of isolated potassium atoms with hybridized orbitals in catalytic oxidation, Chem. Commun., 2015, 51, 9888-9891.

22 M. Ding, Y. Yang, J. Xu, Z. Tao, H. Wang, H. Wang, H. Xiang and Y. Li, Effect of reduction pressure on precipitated potassium promoted iron-manganese catalyst for FischerTropsch synthesis, Appl. Catal., A, 2008, 345, 176-184.

23 J. Iranmahboob, D. O. Hill and H. Toghiani, Characterization of $\mathrm{K}_{2} \mathrm{CO}_{3} / \mathrm{Co}^{-\mathrm{MoS}_{2}}$ catalyst by XRD, XPS, SEM, and EDS, Appl. Surf. Sci., 2001, 185, 72-78.

24 G. P. Huffman, N. Shah, J. Zhao, F. E. Huggins, T. E. Hoost, S. Halvorsen and J. G. Goodwin Jr, In situ XAFS investigation of K-promoted Co catalysts, J. Catal., 1995, 151, 17-25.

25 F. E. Huggins, N. Shah, G. P. Huffman, F. W. Lytle, R. B. Greegor and R. G. Jenkins, In situ XAFS investigation of $\mathrm{Ca}$ and $\mathrm{K}$ catalytic species during pyrolysis and gasification of lignite chars, Fuel, 1988, 67, 1662-1667.

26 R. Ramdas, E. Nowicka, R. Jenkins, D. Sellick, C. Davies and S. Golunski, Using real particulate matter to evaluate combustion catalysts for direct regeneration of diesel soot filters, Appl. Catal., B, 2015, 176-177, 436-443.

27 J. P. A. Neeft, M. Makkee and J. A. Moulijn, Metal oxides as catalysts for the oxidation of soot, Chem. Eng. J., 1996, 64, 295-302.

28 D. Fino, N. Russo, G. Saracco and V. Specchia, Removal of $\mathrm{NO}_{x}$ and diesel soot over catalytic traps based on spinel-type oxides, Powder Technol., 2008, 180, 74-78.

29 Y. Wei, Z. Zhao, J. Liu, S. Liu, C. Xu, A. Duan and G. Jiang, Multifunctional catalysts of three-dimensionally ordered macroporous oxide-supported Au@Pt core-shell nanoparticles with high catalytic activity and stability for soot oxidation, J. Catal., 2014, 317, 62-74.

30 W. F. Shangguan, Y. Teraoka and S. Kagawa, Promotion effect of potassium on the catalytic property of $\mathrm{CuFe}_{2} \mathrm{O}_{4}$ for the simultaneous removal of $\mathrm{NO}_{x}$ and diesel soot particulate, Appl. Catal., B, 1998, 16, 149-154.

31 H. An, C. Kilroy and P. J. McGinn, Combinatorial synthesis and characterization of alkali metal doped oxides for diesel soot combustion, Catal. Today, 2004, 98, 423-429.

32 G. Corro, U. Pal, E. Ayala and E. Vidal, Diesel soot oxidation over silver-loaded $\mathrm{SiO}_{2}$ catalysts, Catal. Today, 2013, 212, 63-69.

33 R. Matarrese, L. Castoldi, L. Lietti and P. Forzatti, Soot combustion: Reactivity of alkaline and alkaline earth metal oxides in full contact with soot, Catal. Today, 2008, 136, 11-17.

34 M. S. Gross, M. A. Ulla and C. A. Querini, Catalytic oxidation of diesel soot: New characterization and kinetic evidence related to the reaction mechanism on $\mathrm{K} / \mathrm{CeO}_{2}$ catalyst, Appl. Catal., A, 2009, 360, 81-88.

35 L. Castoldi, R. Matarrese, L. Lietti and P. Forzatti, Intrinsic reactivity of alkaline and alkaline-earth metal oxide catalysts for oxidation of soot, Appl. Catal., B, 2009, 90, 278-285.

36 A. Nzihou, B. Stanmore and P. Sharrock, A review of catalysts for the gasification of biomass char, with some reference to coal, Energy, 2013, 58, 305-317.

37 J. J. Rehr, J. J. Kas, F. D. Vila, M. P. Prange and K. Jorissen, Parameter-free calculations of X-ray spectra with FEFF9, Phys. Chem. Chem. Phys., 2010, 12, 5503-5513. 
38 J. J. Rehr, J. J. Kas, M. P. Prange, A. P. Sorini, Y. Takimoto and F. Vila, $\mathrm{Ab}$ initio theory and calculations of X-ray spectra, C. R. Phys., 2009, 10, 548-559.

39 R. L. Lehman, N. G. Glumac and J. S. Gentry, Thermal stability of potassium carbonate near its melting point, Thermochim. Acta, 1998, 316, 1-9.

40 A. P. de Kroon, G. W. Schaefer and F. Aldinger, Direct Synthesis of Binary K- $\beta$ - and K- $\beta$ "-Alumina. 1. Phase Relations and Influence of Precursor Chemistry, Chem. Mater., 1995, 7, 878-887.

$41 \mathrm{~J}$. Sokolowski and A. Kotarba, The structure of potassium aluminium oxide $\mathrm{KAlO}_{2}$, Mater. Sci. Forum, 2000, 321-324, 954-959.

42 M. Kantschewa, E. V. Albano, G. Ertl and H. Knoezinger, Infrared and X-ray photoelectron spectroscopy study of potassium carbonate/ $\gamma$-alumina, Appl. Catal., 1983, 8, 71-84.
43 C. Sugiura and S. Muramatsu, K-edge X-ray absorption spectra from potassium compounds, Phys. Status Solidi B, 1985, 132, K111-K115.

44 C. M. Dutta and H. W. Huang, K-edge absorption spectra of ionic potassium and its $\mathrm{Z}+1$ analogy, Phys. Rev. Lett., 1980, 44, 643-646.

45 S. Iqbal, S. A. Kondrat, D. R. Jones, D. C. Schoenmakers, J. K. Edwards, L. Lu, B. R. Yeo, P. P. Wells, E. K. Gibson, D. J. Morgan, C. J. Kiely and G. J. Hutchings, Ruthenium Nanoparticles Supported on Carbon: An Active Catalyst for the Hydrogenation of Lactic Acid to 1,2-Propanediol, ACS Catal., 2015, 5, 5047-5059.

46 J. A. Ibers, J. Kumamoto and R. G. Snyder, Structure of potassium hydroxide: an X-ray and infrared study, J. Chem. Phys., 1960, 33, 1164-1170. 